\title{
Device Alarm not Visible
}

National Cancer Institute

\section{Source}

National Cancer Institute. Device Alarm not Visible. NCI Thesaurus. Code C63309.

A device does not display an alarm message when required. 